\title{
ANALISA KESIAPAN GURU DAN STAFF SEKOLAH DALAM SISTEM PEMBELAJARAN DIMASA NEW NORMAL
}

\author{
Jhon William*, Novita Vera Manalu \\ Fakultas Ilmu Keperawatan, Universitas Advent Indonesia, Jl. Kolonel Masturi No.288, Cihanjuang \\ Rahayu, Kec. Parongpong, Kabupaten Bandung Barat, Jawa Barat 40559, Indonesia \\ *Jhonwilliam181098@gmail.com (+6281770420341)
}

\begin{abstract}
ABSTRAK
Dalam dunia pendidikan saat pandemi Covid-19 sekolah - sekolah harus melakukan pembelajaran di rumah saja atau lebih dikenal dengan daring, hal ini membuat kurang efektifnya sistem pembelajaran karena guru tidak dapat memantau secara langsung sistem pembelajaran siswa dirumah. Saat ini pemerintah sedang gencar dalam mensosialisasikan kebijakan New Normal atau kebiasaan baru dimana kebijakan ini dapat di artikan sebagai perubahan aktivitas prilaku masyarakat secara normal dengan prosuder kesahatan yang dianjurkan oleh Pemerintah. Penelitian ini memiliki tujuan untuk menganalisa bagaimana kesiapan Guru dan Staff Sekolah SMA Advent Cimindi dalam sistem pembelajaran di masa New Normal. Metode penelitian yang digunakan oleh peneliti yaitu metode penelitian deskriptif kualitatif dimana peneliti memberikan kuisioner kepada 10 responden yang berisikan Guru dan Staff Sekolah. Dan dari hasil yang telah di peroleh maka di dapati $75 \%$ responden siap dalam melakukan sistem pembelajaran dimasa New Normal hal ini dapat dilihat dari jawab yang diberikan oleh responden kepada peneliti melalui kuisioner sehingga Sekolah SMA Advent Cimindi telah siap dalam melakukan sistem pembelajaran dimasa New Normal dengan mengikuti aturan kesehatan yang sudah diatur oleh Pemerintah.
\end{abstract}

Kata kunci: kesiapan guru dan staff sekolah; new normal; pendidikan

\section{READINESS ANALYSIS OF TEACHERS AND SCHOOL STAFF IN THE NEW NORMAL LEARNING SYSTEM}

\begin{abstract}
In the world of education during the Covid-19 pandemic, schools had to do learning at home or better known as online, this made the learning system less effective because teachers could not directly monitor student learning systems at home. Currently the government is intensively disseminating the New Normal policy or new habits where this policy can be interpreted as a change in normal community behavior activities with health procedures recommended by the Government. This study aims to analyze how the readiness of teachers and staff of the Cimindi Adventist High School in the learning system in the New Normal period. The research method used by the researcher is descriptive qualitative research method in which the researcher gives questionnaires to 10 respondents containing teachers and school staff. And from the results that have been obtained, it is found that $75 \%$ of respondents are ready to carry out the learning system in the New Normal this can be seen from the answers given by respondents to researchers through questionnaires so that the Cimindi Adventist High School is ready to carry out the learning system in the New Normal with comply with the health regulations set by the government.
\end{abstract}

Keywords: education; new normal; readiness of teacher`s and school staff

\section{PENDAHULUAN}

Pada awal tahun 2020 indonesia harus menghadapai wabah pandemic Covid19, hingga saat ini wabah Covid-19 masih menyebar di indonesia menurut data yang diperoleh dari Covid19.go.id pada tanggal 4 Maret 2021 jumah pasien positif berjumlah $1,361,098$. Hal ini juga yang membuat harus terhentinya segala aktivitas yang melibatkan banyak orang khsusunya dalam dunia pendidikan, setelah 
pemerintah memutuskan untuk melakukan pembatasan kegiatan masyarakat maka kegiatan sosial sangat dibatasi khususnya dalam dunia pendidikan hal ini di lakukan untuk upaya dalam memberantas Covid-19, Penutupan sekolah adalah tindakan terhadap pandemi Covid-19 yang mempengaruhi akses ke pendidikan, lebih dari 370 siswa sekolah tidak dapat mengikuti sistem pembelajaran secara tatap muka, hal ini dikarenakan upaya pemerintah dalam memutus mata rantai penyebaran Covid-19 maka pelayanan kegiatan masyarakat ditutup sementara khususnya sekolah (Saepudin, 2020).

Pada saat pemerintah sedang mengupayakan untuk dapat membuka kembali sektor - sektor yang sempat terhenti oleh karena penyebaran virus Covid-19, sektor - sektor yang di maksud meliputi Pendidikan, Ekonomi, Industri, dan Pariwisata, dalam upaya membuka kembali sektor - 2sektor yang terhenti pemerintah sedang mengupayakan penerapan system New Normal, New Normal ini ialah memberlakukannya kembali kegiatan atau aktivitas masyarakat umumnya, namun tetap dilaksanakannya dengan protokol kesehatan seperti menjaga jarak satu sama lain minimal satu meter, selalu rajin mencuci tangan dengan sabun atau dapat juga menggunakan hand sanitizer, selalu menggunakan masker saat berpergian keluar rumah, dan dianjurkan untuk tetap diam dirumah saja untuk yang sakit.

Hal ini juga yang akan diterapkan oleh sekolah - sekolah yang ada di seluruh Indonesia, menurut pandangan pengamat pendidikan, pendidikan di Indonesia bisa dikatan siap dalam menghadapi New Normal. Namun, kesiapan tersebut sangat dipengaruhi pada kejelasan panduan kebijaan New
Normal yang dicetuskan oleh pemerintah. Jika bentuk kebijakan New Normal yang dimaksudkan pembukaan sekolah dengan menerapkan protokol kesehatan yang ketat, sehingga ada beberapa panduan atau aturan yang harus menjadi perhatian, seperti kesiapan sekolah dalam menyiapkan tempat cuci tangan, sabun pencuci tangan atau hand sanitizer, tim kesehatan, dan lain-lain.

Kesiapan Guru maupun staff sekolah menjadi peran penting dalam kesiapan sekolah meghadapi New Normal, tidak hanya itu sekolah juga harus mempersiapkan segala kondisi baik teknis maupun materi yang akan diberikan. Ada beberapa kebijakan yang harus diikuti oleh sekolah dalam membuka kembali sekolah di masa pandemic khususnya dalam system New Normal menurut (Suprijono,2020) dalam buku kesiapan dunia pendidikan menghadapi era new normal syarat itu terdiri dari 19 item yaitu: 1)Proses skrining kesehatan Guru dan karyawan sekolah, 2)Skrining zona lokasi sekolah, 3)Lakukan tes Covid-19, 4)Tanda lulus skrining, 5)Sosialisasi virtual, 6)Atur waktu KBM (kegiatan belajar mengajar), 7)Membuat data mengenai kondisi kesehatan siswa, 8)Mengatur posisi duduk siswa, 9)Guru tetap, 10)Jaga jarak ideal, 11)Membatasi jumlah siswa dan jadwal masuk, 12)Tidak berkumpul, 13)Skrining fisik , 14)Penerapan PHBS (Perilaku Hidup Bersih dan Sehat), 15)Sosialisasi dalam kelas, 16)Disinfektan, 17)Penutupan Tempat bermain, 18)WFH (Work from Home) 19)Pemberdayaan UKS. Penelitian ini bertujuan untuk mengetahui kesiapan sekolah dalam melakukan persiapan menghadapi system New Normal, dalam upaya mencegah terjadinya penularan virus Covid - 19 di lingkungan sekolah. 


\section{METODE}

Metode penelitian yang gunakan adalah metode deskriptif kualitatif, penelitian ini menggunakan kuisioner yang sudah valid atas ijin pembuat kuesioner dengan jumlah 15 pertanyaan yang mendeskripsikan kesiapan guru dan staff sekolah dalam menghadapi pembelajaran offline di masa New Normal. Data dianalisis secara univariat.

\section{HASIL}

Hasil penelitian ini penulis meggunakan kuisioner dengan jenis kuisoner yang biasanya diklarifikasi menjadi 3 bagian meliputi : tertutup, terbuka, dan tertupterbuka. Pada umumnya Kuesioner merupakan teknik pengumpulan data yang dilakukan dengan cara memberi seperangkat pertanyaan atau pernyataan secara tertulis kepada responden untuk dijawabnya. (Sugiyono, 2005:162).

Dalam penelitian ini penulis menggunakan kuisoner yang di adaptasi dari kuisioner milik (Wahyuni Sri, 2020) dengan metode terbuka, peneliti akan memberikan keleluasaan bagi informan untuk menuliskan sendiri jawaban dari daftar pertanyaannya. Pembagian kuesioner dengan metode terbuka dilakukan terhadap guru dan staff sekolah dengan jumlah 10 Orang pada sekolah SMA Advent Cimindi, lembar kuesioner akan dibagikan melalui google form yang linknya akan dibagikan melalui aplikasi whatsapp.

Hasil penelitian yang sudah di dilakukan maka di dapati hasil sebgai berikut:

1. Apa yang Bapak/Ibu ketahui tentang New Normal yang dicanangkan pemerintah? Berdasarkan jawaban yang telah diberikan maka disimpulkan sebagai berikut New Normal merupakan suatu kebiasan baru dimana masyarakat akan membiasakan diri untuk kembali normal namun dengan tetap menjalankan anjuran prokes yang telah di atur oleh pemerintah, namun juga ada responden yang menjawab bahwa New Normal adalah adaptasi kebiasaan baru dari masa krisis kemasa normal.

2. Bagaimana pendapat Bapak/Ibu mengenai pembelajaran pada masa New Normal? Berdasarakan pemaparan yang diasampaikan rata rata responden setuju dilakukaknya kembali sistem pembelajaran tatap muka di masa New Normal ini tetapi dengan melaksanakan protokol kesehatan yang diatur oleh pemerintah, namun juga ada responden yang menolak dengan alasan masih berersiko apabila dilakasanakan pembelajaran tatap muka.

3. Bagaimana cara Bapak/Ibu melaksanakan kegiatan pembelajaran di sekolah pada saat pemberlakuan New Normal? Responden menjawab agar tetap mengikuti aturan prokes yang dianjurkan oleh pemerintah.

4. Bagaimana cara Bapak/Ibu mengarahkan siswa saat kegiatan pembelajaran berlangsung di sekolah pada masa New Normal? Berdasarkan jawaban yang telah di sampaikan bahwa responden meberikan jawaban untuk memberikan sosialisasi untuk tetap mengikuti protokol kesehatan seperti menggunakan masker saat di lingkungan sekolah, selalu mencuci tangan, menjaga jarak, dan menghindari kerumunan. 
5. Apakah ada peraturan dari pemerintah mengenai pembelajaran disekolah pada masa New Normal yang di dapat oleh sekolah? Rata rata responden menjawab belum mendapatkan aturan yang pasti, hal ini dikarenakan belum adanya sosialisasi kembali anatara kementrian pendidikan dan sosial budaya dengan para kepala sekolah di seluruh Indonesia.

6. Apa rencana Bapak/Ibu dalam menerapkan peraturan pembelajaran pada masa New Normal? Berdasarkan jawaban dari para responden mereka akan menerapkan aturan yang sudah di atur oleh pemerintah dan kemudian sekolah akan membuat aturan khusus untuk tetap menjaga siswa, guru, dan staff sekolah terhindar dari penyebaran Covid-19.

7. BagaimanaBapak/Ibu menerapkan protokol kesehatan untuk siswa di lingkungan sekolah? Responden menjawab dengan cara melakukan langkah - langakah seperti mencuci tangan, menjaga jarak, menggunakan masker, menjahui kerumunan, mengurangi mobilitas, dan selalu memberikan sosialisasi untuk tetap menjaga dan terhindar dari penularan virus Covid-19.

8. Apa yang akan Bapak/Ibu lakukan saat melihat seorang siswa tidak mengikuti protokol kesehatan di sekolah? Menurut jawaban yang telah diberikan maka disimpulkan bahwa siswa yang melanggar akan di berikan teguran terlebih dahulu kemudian di berikan pengertian tetang pentingnya mengikuti protokol kesehatan untuk kamanan dan kenyamanan bersama.
9. Bagaimana cara penanganan Bapak/Ibu, jika ada siswa yang memiliki gejala Covid-19 dikelas? Rata - rata para responden menjawab untuk menempatkan siswa di ruang Isolasi Sekolah kemudian pihak Sekolah akan menghubungi orang tua terlebih dahulu untuk mendapatkan persetujuan dan mengetahui kabar dari anaknya untuk di rujuk ke Puskesmas, atau Rumah sakit terdekat.

10.Bagaimana cara Bapak/Ibu bekerja sama dengan orang tua siswa dalam memantau kegiatan siswa dirumah? Berdasarkan jawaban yang di peroleh maka jawabnya para Wali kelas akan membuat grup khusus dengan Orang tua siswa untuk memantau kegiatan pembelajaran siswa dirumah.

11.Apakah ada perubahan dengan kegiatan pembelajaran disekolah saat sebelum pandemi covid-19 dengan masa pemberlakuannya New Normal? Jika iya coba jelaskan! Menurut jawaban yang telah disampaikan oleh respoden rata rata responden menjawab kuragnya kontak langsung dengan siswa menjadi salah satu factor yang membuat perubahan kegitan belajar, hal ini disebakan karena adanya pembagian jadwal untuk siswa yang masuk kedalam sekolah, sekolah hanya dapat menapung $50 \%$ saja jumlah orang yang berada didalam sekolah sedangkan sisanya akan mengikuti sistem pembelajaran dirumah atau secara daring.

12.Bagaimana Bapak/Ibu mengatur jam istirahat agar siswa tidak bergerombol? Jawaban yang di berikan oleh responden sangat beragam dan rata - rata jawaban dari responden menjawab bahawa di 
tiadaknya jam istirahat hal ini dikarenakan terbatasnya jam pembelajaran, sehingga untuk mencegah terjadinya kerumunan maka responden lebih memilih untuk di tiadaknya jam istirahat.

13.Bagaimana cara Bapak/Ibu mengelola kelas dalam masa New Normal di sekolah? Berdasarkan hasil yang diperoleh maka guru ataupun walikelas akan mengatur jarak duduk siswa dan juga mengantur didalam ruang kelas hanya dapat di isi $15-25 \%$ siswa saja dan sisanya akan mengikuti melalui daring secara online, kemudian walikelas akan membuat jadwal untuk setiap siswa dapat masuk sekolah secara bergantian, dan guru yang mengajar akan tetap mengingatkan untuk tetap menaati prokes.

14.Bagaimana cara Bapak/Ibu membuat siswa nyaman saat melaksanakan kegiatan pembelajaran di sekolah pada masa New Normal? Tanggapan yang diberikan oleh responden sangatlah beragam dan dapat disimpulkan bahwa responden akan lebih membuat pembelajaran itu lebih ringkas dan efisien agar pelajaran yang di sampaikan tidak membuat siswa merasa terbebani dan mudah untuk dipahami, rata - rata responden juga akan tetap memberikan motivasi untuk siswa agar tetap semangat dalam mengikuti pembelajaran di masa New Normal ini.

\section{Bagaimana cara Bapak/Ibu} mengarahkan siswa saat kegiatan pembelajaran di sekolah pada masa New Normal dari sebelum memasuki kelas sampai kegiatan pembelajaran selesai dilaksanakan? Rata - rata responden menajawab tetap melakukan protokol kesehatan saat berada dilingkungan sekolah guru dan staff akan tetap memantau siswa.

\section{PEMBAHASAN}

Pada penelitian ini peneliti membahas bagaimana sistem pembelajaran di masa New Normal dimana diberlakukanya 2 metode pembelajaran yaitu metode daring atau sering disebut dengan online dan metode tatap muka atau offline, berdasarkan pandangan Noord et al(2007). metode pembelajaran Blended adalah suatu cara dalam menggabungakan berbagai bentuk pembelajaran yaitu daring, luring dan tatap muka (in-Person Learning). Pada metode pembelajaran Blended Learning merupakan proses pembaharuan dalam sistem pembelajaran daring dengan mencoba mengintegrasikan inovasi dalam teknologi pembelajaran dengan pembelajaran secara tradisional yaitu pembelajaran yang harus selalu berhubungan dan berpartisipasi secara langsung. Throne (2003), sistem pembelajaran Blended Learning adalah sistem penggabungan dari aspek sistem pembelajaran tatap muka dengan sistem pembelajaran daring dengan tujuan tercapainya efektifitas belajar yang optimal.

Berdasarakan hasil yang telah didapati dari para responden maka rata - rata responden telah memahami pengertian dari New Normal dan dapat menerapakan aturan kesehatan yang sudah di atur oleh Pemerintah, Guru dan Staff Sekolah memiliki peranan penting dalam sistem pembelajaran di masa New Normal hal ini dapat dinilai dari bagaimana responden memberikan jawaban melalui kuisioner diberikan, seperti halnya ketika guru dan staff sekolah membatasi jumlah murid yang masuk kedalam kelas atau kedalam 
lingkungan sekolah yang dimana hanya dapat di isi 15 - $25 \%$ murid saja dan tetap mengikuti 3M ( Mencuci tangan, Menggunakan masker, Menjaga jarak).

Pada pertanyaan menegenai perubahan kegiatan pembelajaran disekolah saat sebelum pandemi covid-19 dengan masa pemberlakuannya New Normal ? pada penelitian lain rata rata responden menjawab kurangnya kontak langsung dan pengawasan terhadap siswa, tetapi pada penelitian yang telah dilakukan rata - rata responden meberikan jawaban keterbatasanya ruang gerak dalam mengajar menjadi faktor utama yang membuat guru dan siswa mengalami perbuhan dalam sistem pembelajaran, menurut pandangan Wulandari (2018). Guru memiliki tugas dalam mengembangkan profesi pendidik serta menjalakan tugas dan tanggung jawabnya dalam menyesuaikan kebutuhan siswa dan melakukan pengembangan materi pembelajaran sesuai dengan perkembangan zaman.

Tidak hanya itu permasalahan yang harus dihadapi juga ialah sistem pembelajaran melalui daring menurut Handarini (2020). penegertian dari daring sendiri ialah sistem pembelajaran yang dilakukan secara online dengan jarak jauh atau pembelajaran yang dilakukan peserta didik dimanapun dan kapanpun saat dibutuhkan, sehingga sangat dibutuhkanya sarana dan pra sarana yang memadai seperti komputer, handphone, dan jaringan internet yang dapat mendukung proses pembelajaran melalui daring.

Guru merupakan sosok yang harus di contoh dalam menerapkan protokol kesehatan, oleh sebab guru adalah sosok yang selalu berinteraksi langsung dengan siswa maka dari itu guru haruslah menjadi contoh dalam menjalankan protokol kesehatan.

Protokol kesehatan yang diatur oleh pemerintah merupakan seusatu yang sangat penting dijalankan dalam upaya memutus mata rantai peneyebaran Covid -19, aturan dan protokol kesehatan harus diterapkan di lingkungan sekolah dan sangat menjadi konsen bagi Guru dan Staff Sekolah dikarenakan dalam upaya membuka sekolah di masa New Normal ini sekolah harus berhati - hati agar murid dan guru maupun staff terhidar dari penyeberan Covid -19. Tetapi tidak semua Guru dan Staff Sekolah setuju terhadap pembukaan sekolah di masa New Normal ini hal ini dikarenakan masih rawanya penyebaran Covid - 19 dan juga rata - rata guru sudah lanjut usia sehigga rentan terkena penyakit.

\section{SIMPULAN}

Berdasarakan hasil dari semua jawaban yang sudah di teliti maka dapat disimpulkan bahwa Guru dan Staff Sekolah SMA Advent Cimindi siap dalam melakukan sistem pembelajaran di masa New Normal ini hal ini dapat dilihat dari analysis kesiapan Guru dan Staff sekolah dalam sistem pembelajaran dimasa New Normal dimana Guru dan Staff Sekolah mengikuti aturan yang di anjurkan oleh pemerintah seperti pembatasan jumlah murid yang berada didalam kelas yang hanya di isi oleh $15-25 \%$ murid saja dan sisanya belajar memalui daring secara online dan hal itu dibuat melalui shift atau bergantian agar semua siswa dapat merasakan pembelajaran tatap muka, kemudian dijalankanya protokol kesehatan yang di atur oleh pemerintah, tidak hanya itu saja pihak sekolah pun melakukan pembersihan kelas dengan menyemprotkan disinfektan untuk 
mencegah penyebaran virus, Sekolah SMA Advent Cimindi juga memiliki ruang UKS yang dimana ruangan tersebut dipergunakan untuk mealakukan isolasi terhadap Guru dan Staff Sekolah maupun siswa apabila dicurigai terpapar virus Covid-19

\section{DAFTAR PUSTAKA}

Alzoubi, H. e. (2020). Covid 19 knowledge, Attitude and Practiceamong Medical and Non Medical. Journal of Pure and Applied Microbiology.

Diana Eka, D. (2020). ANALISIS METODE PEMBELAJARAN EFEKTIF DI ERA. Jurnal ReviewPendidikan dan Pengajaran, III, 336 - 342.

Firman. (2020). Pembelajaran Online di Tengah Pandemi Covid-19 (Vol. II). Indonesian Journal of Educational Science.

Firmansyah, Y. (2020). Pengaruh New Normal Ditengah Pandemi Covid19. IV, 99 - 112.

Handarini, O. I. (2020). Pembelajaran Daring Sebagai Upaya Study From Home (SFH) (Vol. VIII). Jurnal Pendidikan Administrasi Perkantoran (JPAP).

Herliandry, L. D. (2020). Pembelajaran Pada Masa Pandemi Covid-19 (Vol. XXII). JTP - Jurnal Teknologi Pendidikan.

Indonesia, G. T. (2020). Data COVID19 Global dan Indonesia.(Online). https://covid19.go.id/ . (4 Maret 2020).

Jalal, M. (2020). Kesiapan Guru Menghadapi Pembelajaran Jarak Jauh Di Masa Covid-19 (Vol. II).
SMART KIDS: Jurnal Pendidikan Islam Anak Usia Din.

Muhammad Marshal Nugroho, D. (2020). Analisis Kesiapan Pelaksanaan Kegiatan Pembelajaran (Vol. III). Journal Publicuho.

Nana, S. (2004). Dasar-Dasar Proses Belajar Mengajar. Bandung : Remaja Rosdakarya. .

Noor.id, S. (2007). E-Learning Models: A Review Of Lirerature. The 1st International Conference on.

Purnama, M. N. (2020). Blended Learning Sebagai Sarana Optimalisasi Pembelajaran Daring (Vol. II). Jurnal Pendidikan Islam dan Multikulturalisme.

Putra, Y. I. (2020). Tingkat Pengetahuan Dengan Perilaku Warga Dalam Menjalankan. vol VIII, 366- 373.

Sri Wahyuni Saepudin, D. (2020). Menganalisis Peran Guru Mengenai Kesiapan Kegiatan Pembelajaran Dalam Mengahadapi Masa New Normal di Sekolah Dasar (Vol. III). JURNAL PERSEDA.

Suprijono, A. (2020). Kesiapan Dunia Pendidikan Menghadapi Era New Normal. IAIN Parepare Nusantara Press.

Thorne, K. (2003). Blended learning : How to Integrate Online and Traditional Learning. London: Kogan Page Limited. . 
Jurnal Penelitian Perawat Profesional, Volume 3 No 2 Hal 413 - 420, Mei 2021 Global Health Science Group 